(昭和 38 年 2 月 12 日受理)

\title{
分散染料とポリプロピレン繊維との相互作用
}

\author{
大厉府立大学工学部片山明・黑木宣 \\ 応用化学教室小西幛三
}

\section{THE INTERACTION BETWEEN POLYPROPYLENE FIBRE AND DISPERSE DYES}

By Akira Katayama, Nobuhiko Kuroki and Kenzö Konishi

(Dept, of Applied Chemistry, College of Engineering, University of Osaka

Prefecture, Osaka, Japan.)

The absorption isotherms of four disperse dyes for polypropylene fibers were determined at various: temperatures. The affinity, heat of dyeing and entropy of dyeing were calculated from the thermodynamical treatment. The heats of dyeing of all four dyes investigated were all negative, so. the binding process was exothermic. The affinity of the dye for polypropylene was found to increase with the increase in the hydrophobic character of the dye. The increase in the hydrophobic character of the dye, however, causes the decrease in the heat and entropy of dyeing. This result shows that the higher affinity of the hydrophobic dye comes from the decrease in the entropy of dyeing. From a consideration of the thermodynamical data, it is assumed that the breakdown of so called "iceberg" water structure in the vicinity of the hydrophobic dye takes place in the courseof the binding process. The interaction between polypropylene fibre and disperse dye is explained by using the following concept that the binding process involves two main effects : (1) an exothermic interaction (may be dispersion force) (2) an entropic interaction (the formation of a so called: "hydrophobic bond")

(Received February 18, 1963)

\section{1. 緒言}

分散染料によるポリプロピレン䋐維の染色に䦰して

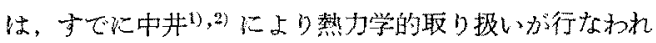
て㤁り，染粼が染浴から織維中八移行子る際には熱心吸 取於よびエントロビーの增大をともならものと報告さ れ，その染色機搆は染料の緎䧽に対する溶解機樭による ものとされている。

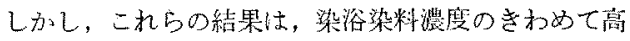
い, 固体染料の共存高马上思われる条件下に拈いて得ら れた当のである。

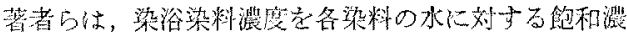

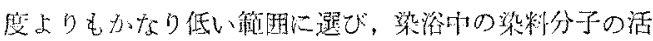

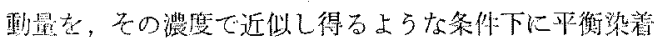

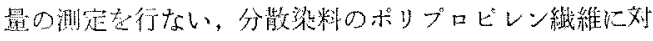

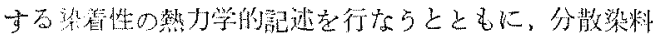

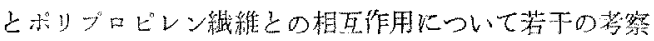
姑なった。

\section{2. 試料および測定方法}

試料……用いた染料は，下に示した4種のモノアゾ型
分教染料である。これらの染料は，台成昆をクロルベン ゼンおよびエタノールから再結晶することにより精製 し，純品と思和れるすのを使用した。デューマ浩による

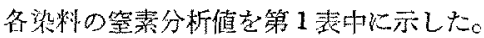

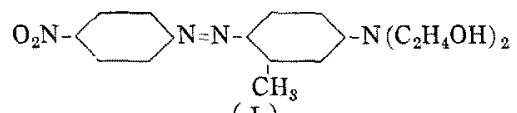

(I)<smiles>CCN(CC)C1CCC(N=NC2C(Cl)CC([N+](=O)[O-])CC2Cl)C(C)C1</smiles>

(II)

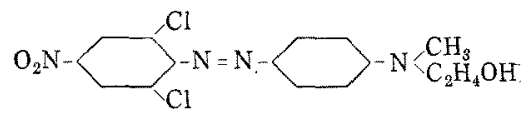

(III)

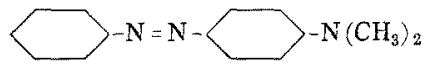

(N)

用いた纎維は，線状ポりプロピレン（アビサン）を $0.5 \%$ 石け儿水溶液中で $80 \sim 90^{\circ} \mathrm{C}$ に 30 分間処理し，

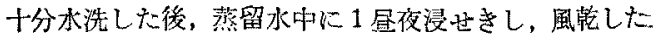


るのである。

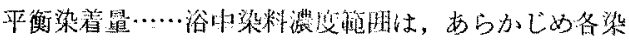

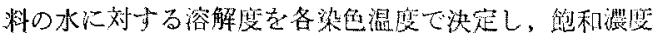

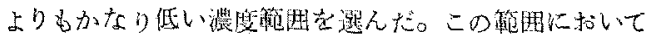

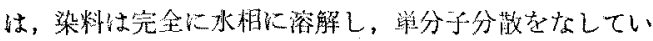

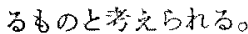

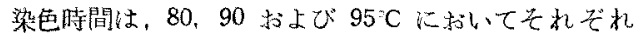

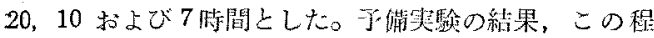

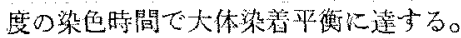

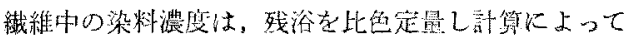
求如。

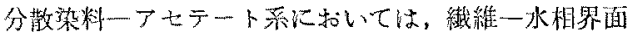

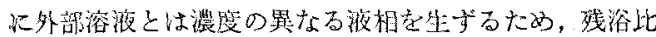

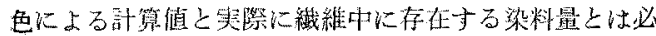

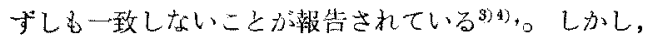
Vickerstafis) によれば同者の間の不一致はさして大きな ものではなく，したがって分散染料一ポリプロピレン系

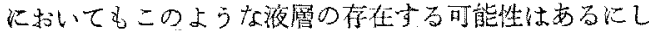

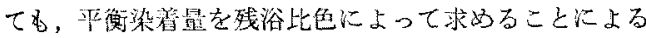
重大な支障はない名のと考良られる。

\section{3. 結 果}

上記 4 種の染料の 80 ，90 お上び 95 C に和ける水に 対主る溶解度老第1站中心示した。

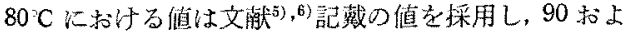

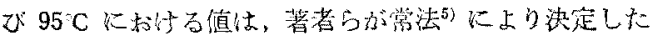
女のである。

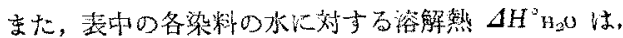

$$
\Delta H^{\circ} \mathrm{H}_{2} \mathrm{O}=R \cdot d \ln S_{T} / d(1 / T)
$$

たたし， $S_{T}$ は各温度に拈ける溶解度，によって訢算し たものである。

第 1 表 各渫料の種々の温度に打ける水儿对子る溶解度

\begin{tabular}{|c|c|c|c|c|c|c|}
\hline \multirow[b]{2}{*}{ 染料 } & \multirow{2}{*}{$\begin{array}{l}\text { 䇪素分 } \\
\text { 析值* }\end{array}$} & \multicolumn{4}{|c|}{ 溶解度 $(\mathrm{mg} / \mathrm{l})$} & \multirow{2}{*}{$\frac{\Delta H^{\circ} \mathrm{H}_{2} \mathrm{O}}{(\mathrm{kcal} / \mathrm{mol})}$} \\
\hline & & $80^{\circ}$ & $90^{\circ}$ & & $95^{\circ}$ & \\
\hline I & $12.1(12.2)$ & $35^{57}$ & 73 & & 106 & 19.1 \\
\hline II & $10.0(10.2)$ & $13^{5 y}$ & 27 & & 37 & 18.6 \\
\hline III & $15.1(15.2)$ & $\left.9.8^{5}\right)$ & 21 & & 29 & 19.3 \\
\hline N & $18.5(18.8)$ & $8^{n>}$ & 14 & & 18 & 14.4 \\
\hline
\end{tabular}

すてに述べたように，染浴染料濃鷹範国は溶解度より

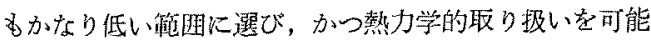
とするため浴中に分散剂を添加することなく各分散染料 のポリプロピレン䋊維に対する染箱温明線を 80,90 扎よ゙ $95^{\circ} \mathrm{C}$ て洪定した。

結果の一部を，第 1 おび第2畻に示した。

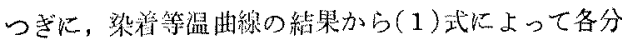

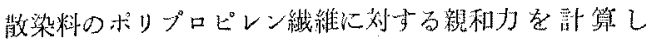
to

$$
-\Delta \mu^{\circ}=R T \ln \left([D]_{F} /[D]_{s} \cdot V\right)
$$

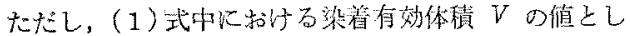

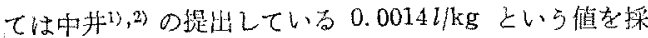
用した。

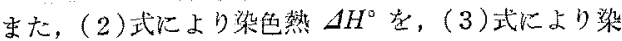
色のエントロピー变化 $A S^{\circ}$ 計算した。

$$
\begin{aligned}
& \Delta H^{\circ}=d\left(\Delta \mu^{\circ} / T\right) / d(1 / T) . \\
& \Delta S^{\circ}=\left(\Delta H^{\circ}-\Delta \mu^{\circ}\right) / T
\end{aligned}
$$

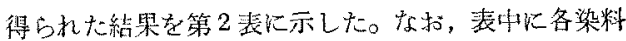

\begin{tabular}{|c|c|c|c|c|c|c|}
\hline \multirow[b]{2}{*}{ 染粦 } & \multicolumn{3}{|c|}{$-\Delta \mu^{\circ}(\mathrm{kcal} / \mathrm{mol})$} & \multirow{2}{*}{$\begin{array}{c}-\Delta H^{\circ} \\
(\mathrm{kcal} / \\
\mathrm{mol})\end{array}$} & \multirow{2}{*}{$\begin{array}{l}-A S^{\circ} \\
(\mathrm{cal} / \\
\mathrm{deg})\end{array}$} & \multirow{2}{*}{ 無機性 } \\
\hline & $80^{\circ}$ & $90^{\circ}$ & $95^{\circ}$ & & & \\
\hline 1 & 6.81 & 6.58 & 6.55 & 13.8 & 20 & 0.98 \\
\hline $\mathbb{I I}$ & 8.18 & 8.03 & 7.87 & 15.2 & 19.8 & 0.86 \\
\hline & 8.77 & 8.70 & 8.61 & 12.3 & 10 & 0.71 \\
\hline $\mathrm{N}$ & 9.13 & 9.25 & 9.23 & 6.5 & -7.6 & 0.46 \\
\hline
\end{tabular}
の然蟣性/有機性值を含合わ让て示した。

第 2 洨 各染料のポリプロピレン瀻維に対する親和 力，染色熱书上び染色のエントロピー变化

\section{4. 䓔察}

第1必加ら明らかなよらに，得られた染筹等温油線は

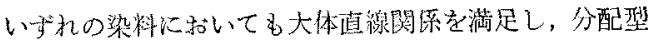
である。

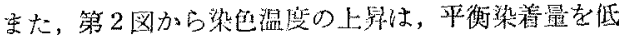
下させ名奻果のあること明らかであり，染色過程が発 熱的て放ること家している。

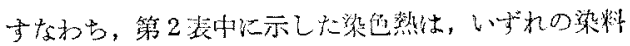

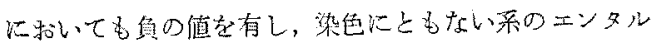
ピーは減少することを寺している。

このような結果は，彷来ア七テート，ポリエステルー 分散染料系について得られている秙棵己類促のものてあ Zo

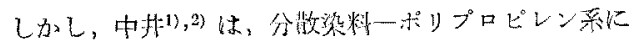

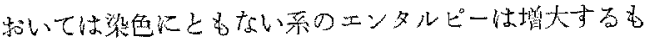

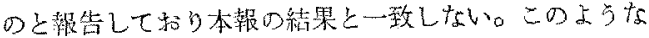

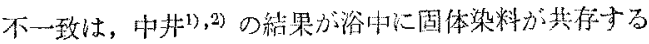
と思われるような条件下に打いて得られたためであるよ 腾光られる。

(1)式により計算された親和力の值拉よび(3)式によ り計算された染色のエントロピー翌化の值は，つぎよ上

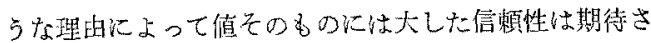
れない。 


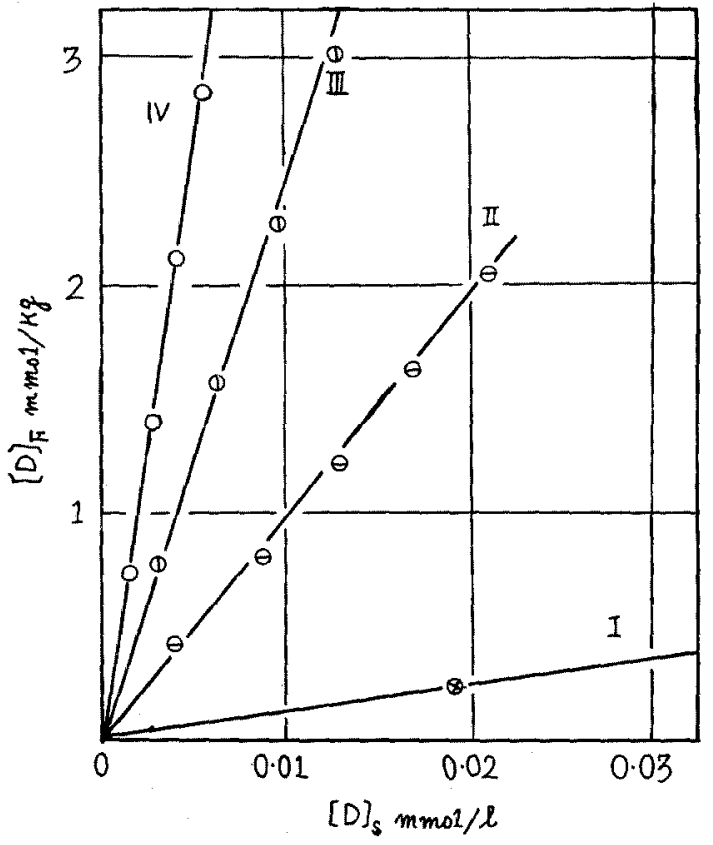

Fig. 1. The absorption isotherms of dyes (I), (II) (III) and (IV) on polypropylene fiber at 90 ${ }^{\circ} \mathrm{C}$.

すなわち，親和力を計算する際必然的に(1)式中に現

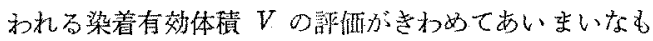
のであるからである。

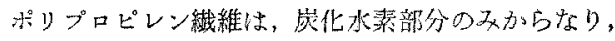
からきかめて高い結晶性を有するため，その染着有効体 䅡Vはかかなり小さいであるらといらことは容易に想像 ざれるが，本報で蜉用した $0.0014 \mathrm{l} / \mathrm{kg}$ という值が妥当 で如るかいなかは明らかでない。

また，染着過程を吸着とみなすかあるいは溶解と欢な

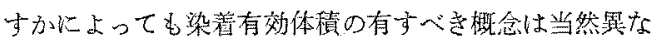

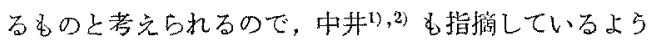
に0.0014 l/kg といら值は全く便宜的沉採用したるのに すぎない。

したがって，(1)式によって計算される親和功拈よび 得られた親和力の值を用いて計算される婪色のエントロ

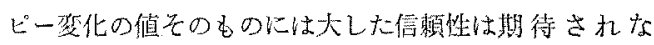
i.

しかし，第 2 丰の蕉力学的ブータを用いて各染料のポ リプロピレンに対する染着性の比校を行ならことは可能 である。

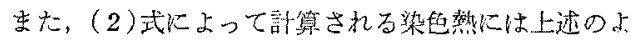
うなあいまいさは存在したい。

分散染料かポリプロピレンに対する染滰珄は，染料の

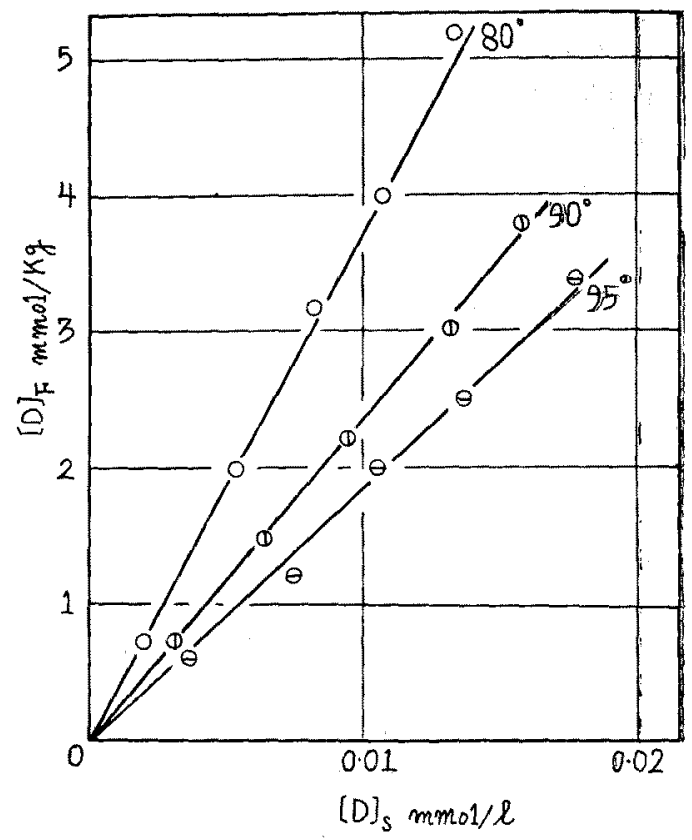

Fig. 2. The absorption isotherms of dyes (III) on polypropylene fiber at various temperatures.

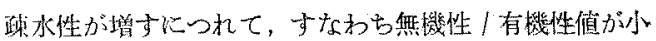
になるにっれて底好となることは寺村・田中てによって 報告されている。

本報では，親和力，染色熱灾さび澡色のエントロピー 変化の 3 種の蓺力学的四数圣用いて各染料のポリプロピ レンに対する染羔性の記述を行ない，染料の無機性/有 機珄值の翏化にともなら染着性の変化はこれらる種の熱 力学的関数のどのよらな奇与に上るむのであるかる考察 する。

第2 䟣から明らかなよらに, 染料の無機性/看機性值 が減少するにつれてその新和力は大亡なる倾回を有し， この絈果は侍村・田中》の結論と一致している。

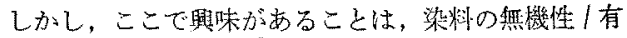
機性值が娍少子るにつれて染色熱和よび染色のエントロ ピ一変化は卆しろ減少する候向を示すことである。

この結果は，染料の無機性/有機性値の減少にともな 方鼠和力の擝大は, 染色熱の增太すなわらエネルギー的 因子の奇与に上万るのではなく，染色のエントロピ一変 化の減少，すな⿰七エントロピー的因子の等与飞上るる。 のであることを慧味する。

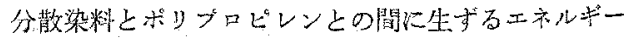
的相互作用としては，主として分散力に上るものが考克 られるが，上の結舆は雨者の閏の相互作用をエネルギー 
的なもののみに限定するかぎり説明困難である。

すなわち，本報の結果は，分散染料一ポリプロピレン 采においては雨者の間にニントロピー的相互作用の働く 可能性のあることを示すむのと若えられる。

Kauzmann $^{8)}$ は，た九白筫分子間の水溶液中に和方 相互作用として棋水性結合 (hydrophobic bond) t大る概 念を提出し，エントロピー的相互作用の重要性を指摘し ている。

すなわち，水溶液中に执いては，たん白筫分子の践水

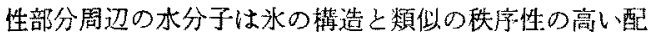
列をとるため采のエントロピーは減少し，なん白筫水溶 湤はエントロピー的にきわわて不安定な状態にあるの で，たん白質分子は互に眯本性部分同志を华着させるこ とによって皮の規則的配列を乱し，エントロピ一的によ り安定な，分子が結合した状態に移行しよらとする傾问 を有するものとしている。

このような結合においては，結合に際し我状構造の融 解に対応して系のエンタルピーおびよエントロピーは㘿 大する。したがって，この種の絬合は，エネルギー的に は不利であるにもかかわらず，むっぱらエントロピ一的 に有利であるためにの狌じ、ニントロピ一的な結合力 でする。

Kauzmann ${ }^{8\rangle}$ は界面活性物質のミ七几形成，可溶性た 几白と酸性染料之の相互作用をむ蹯水性結合で馀じ，ま た Molyneux, Frank ${ }^{9)}$ はボリビニルピロリドンと芳香 族炭化本素間の相互作用を同㥞な考方方で諭じている。

このようなエントロピー的相互作用が染色現哧におい ても存在するかいなかの結諭を下すことはな括今後の䂙 究にまたねばならないとしても，本報の結果は分散染料 一利プロピレン系においては耐者の開にエントロピー 的相互作用の存在する可能性を暗示しておら，また従来 染色現象においては染料一練維間の結合力としてエネル ギー的なものの欢しか考虑されていないので，以下にエ ントロピー的相互作用を乎考慮して分散染料一ポリプロ ピレン間の相互作用を考察してりくことは意味のあるこ とと思和れる。

なお，第 2 表の結果に打いて，染色㷫の值はいずれの 染䉼にお゙いてもすへてて角であるので分教染料一ポリプロ ピレン緎維間には分散力なとに基つくェネルギー的相互 作用も同時存在していることは明らかである。

染着は，染料和よび縅維の脱水和，染料と繊維の結合 および染料一繊維結合体の水和などの過程からなるもの と考奌ると染色熱をつぎの5つの部分にわけることが可 能である。

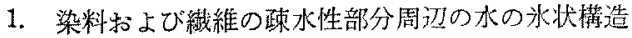
を崩䔩するためのエンタルピー增加 $\Delta H_{1}$

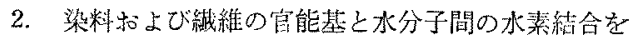
切䋤するためのエンタルピ增加 $\Delta H_{2}$

3. 染料一科維結合体坐成の際のエンタルピー減り $\Delta H_{3}$

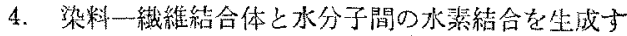
る際のエンタルピー減少 $\Delta H_{4}$

5. 染料一織維結合体䧓辺の水が氷状棈造を形成する 慗のエンタルビー減少 $\mathcal{A} H_{5}$

ここでエエンタルピーに加成性が成立するるのとする 之染色熱 $\Delta H^{\circ}$ は次式で与えられる。

$$
\Delta H^{\circ}=\Delta H_{1}+\Delta H_{2}+\Delta H_{3}+\Delta H_{4}+\Delta H_{5}
$$

分散染料一ポリプロピレン系においては，染料一䋐維 間と氷素結合の先ずる可能性はないので，過程 (2) と過 程 (4)のエンタルピー变化は相殺され

$$
\Delta H_{2}+\Delta H_{4}=0
$$

と考壳ることができる。

したがって

$$
\Delta H^{\circ}=\Delta H_{1}+\Delta H_{3}+\Delta H_{5}
$$

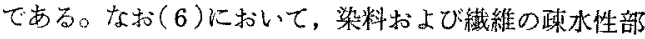
分間には相互作用を生ずるため $\Delta H_{3}+\Delta H_{5} \neq 0$ である。

ここで， $\Delta H_{3}$ は土ネルギー的相互作用（主として分 散力）に対応するエンダルピー变化で $\Delta H_{3}<0$ ，末た $\left(\Delta H_{1}+\Delta H_{5}\right)$ はエントロピー的相互作用に対応する ンタルピー变化で $\left(\Delta H_{1}+\Delta H_{5}\right)>0$ である。

このよらな考え万に基ついて本報の結果を考察してみ 550

まず，染色熱 $\Delta H^{\circ}$ は，いずれの染料においても真の 值であるので

$$
\begin{aligned}
\Delta H^{\circ} & =\Delta H_{3}+\left(\Delta H_{1}+\Delta H_{5}\right)<0 \\
\text { しだがって } & -\Delta H_{3}>\left(\Delta H_{1}+\Delta H_{5}\right)
\end{aligned}
$$

である。

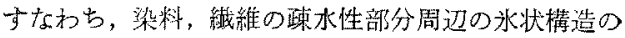

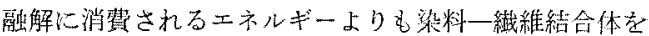
生成古際発生するエホルギーのほらが大であり，水状

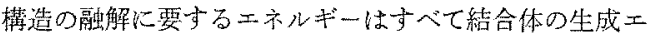
ネルギーによって供給される。

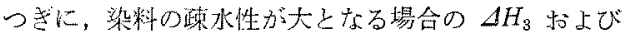
$\left(\Delta H_{1}+\Delta H_{5}\right)$ の窔化を若えてみよう。

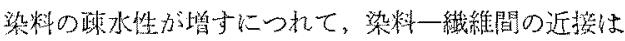

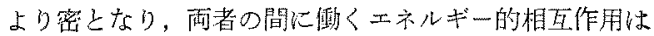
当然大となるものと考名られるので， $\Delta H_{3}$ の負の值は 增大するものと子想される。

しかし，本報の結果上りすれば，染料分子の聚水性の

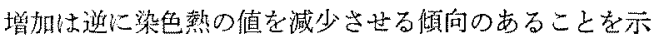
している。 
このような結果は，すでに述べたように分散染料一ポ yプロピレン閒の相互作用としてェネルギー的なものの 又を考えるかぎり説明困難であり、エントロピー的相互 作用に基づく $\left(\Delta H_{1}+\Delta H_{5}\right)$ の变化を考慮してはじめて 颜明可能と思加れる。

すなわち，水分子の規則的配列徒宸化水素周辺儿和い ての々起こるので，染料の瑓水性の增加とともに染料分 子周辺江打汁る水分子の規則的配列は上り大となり，そ の融解に要するエネルギーる大と礼るので $\left(\Delta H_{1}+\Delta H_{5}\right)$ の正の摍は当然大となるであろうし，むた染料一緎維間 の結合は柾水性結合の性格をしだいに強めてくるものと 予想される。

したがって， $\Delta H_{3}$ に比べて $\left(\Delta H_{1}+\Delta H_{5}\right)$ の增加が大 である場合にはこれらの総和としての染色熱 $\Delta H^{\circ}$ の 負の值は染料の政水性が增すにつれて減少する結果とな る。

すなわち，この場合に惊，染料の疎水性の增加に上も なう親和力の增大は，もっばら染料分子周沼の氷状構造 の融解に基つくエントロビーの增大といらェントロビー 的相互作用泟よって達成されるものとして説明される。

以上分散染料一ポリプロピレン瀻維間の結合を，エン トロピー的相互作用の存在を仮定して諭じた。

藷者ら ${ }^{10}$ は，分散染料の水一ベンぜン雨相間の分配を 熟力学的に取り报い，分散染料が水相からベンゼン相へ 移行する際にはエントロピーの增大をともならことを認 めたが，この事実は，染料分子周辺の水分子が水状構造 を形成していることの1つの証拠之考えられる。

また，Molyneux，Frank ${ }^{9}$ (炭化水素周辺の水状構 造の融点として 70`C といら值を推定しているが，常温 付近の水がなかががりの規則性を保持していることを考

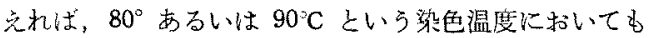
炭化水慗周辺の水分子がな执かなりの規則性を有するむ のと仮定することは一応要当な仮定であると思标れる。
5. 絰括

疎水性の異なる4 種のモノアゾ型分散染料のポりプロ ピレン紸維に対する染着等温曲線を $80^{\circ}, 90^{\circ}$ および $95^{\circ} \mathrm{C}$ で決定し，熱力学的取り扱いを行なった結果

1）いずれの染料においても染色熱は負の值であり， 染着に際し樂のェンタルピーは減少する。

2）染料の䟱水性が增すにつれて，ポリプロピレン緎 維に対する親和力は大となる。

3）染料の蹯水性の增加にともなら親和力の增大は， 染色熱の寄与に上るものではなく染色のエントロピー変 化の笴与によるものである。

ことを明らがし，以上の結果を，分散染料一ポリオ゙ ロピレン繊維間にはエネルギー的相互作用と同時にェン トロピー的相互作用も存在するものと纳定して説明を試

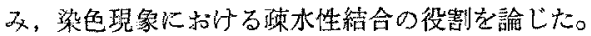

本報告の一部は，昭和 37 年度緘維学会春期研究発䒾 会に皮いて発表したるのである。

\section{文䓟}

1) 中井；䋐学誌，17，878(1961)

2) 中井；工化，65，1390 (1962)

3) Vickerstaff, Waters; J. Soc. Dyer Col., 58, 116 (1942)

4) Skinkle, Sherburne ; Am. Dyestuff Reptr., 46, 749 (1957)

5) Bird; J.Soc. Dyers Col., 70, 68 (1954)

6) Patterson, Sheldon; $J$. Soc. Dyer Col., 76, 178 (1960)

7) 寺村, 田中；䋐学誌、18，436，518，522（1962）

8) Kauzmann; Advances in Protein Chem., 14, 1 (1959)

9) Molyneux, Frank; J. Am. Chem. Soc., 83, 3169 ( 1961$)$

10）片山，黑木, 小西; 昭和 38 年度織維学会架色化 学討論会 (東京) 